\title{
Spindle cell oncocytoma of the pituitary gland
}

\author{
Alexandra M. Giantini Larsen, BS, ${ }^{1}$ David J. Cote, BS, ${ }^{1}$ Hasan A. Zaidi, MD, ${ }^{1}$ \\ Wenya Linda Bi, MD, PhD, ${ }^{1}$ Paul J. Schmitt, MD, ${ }^{2}$ J. Bryan lorgulescu, MD, ${ }^{3}$ \\ Michael B. Miller, MD, PhD, ${ }^{3}$ Timothy R. Smith, MD, PhD, MPH, ${ }^{1}$ M. Beatriz Lopes, MD, PhD, ${ }^{4}$ \\ John A. Jane Jr., MD, ${ }^{2}$ and Edward R. Laws Jr., MD1
}

Departments of ${ }^{1}$ Neurosurgery and ${ }^{3}$ Pathology, Brigham and Women's Hospital, Harvard Medical School, Boston, Massachusetts; and Departments of ${ }^{2}$ Neurosurgery and ${ }^{4}$ Pathology, University of Virginia, Charlottesville, Virginia

OBJECTIVE The authors report the diagnosis, management, and outcomes of 6 cases of spindle cell oncocytoma (SCO) in an effort to guide clinical diagnosis and management of these uncommon lesions.

METHODS This study is a retrospective review of cases involving adult patients who underwent resection of pituitary lesions at the authors' institutions between January 2000 and October 2017. The authors identified patients with histopathological confirmation of SCO and collected clinical data, including preoperative, perioperative, and postoperative management, complications, and outcomes.

RESULTS Six patients with SCO were identified. Clinical findings at initial presentation included visual disturbances, dizziness, and headache. All patients underwent resection. Four resections were initially performed by the transsphenoidal approach, and 2 resections were performed by craniotomy at an outside institution with subsequent transsphenoidal reoperations. Neither necrosis nor increased mitotic activity was seen in the tumor samples. All samples stained positive for S100 protein and thyroid transcription factor 1 and negative for glial fibrillary acidic protein and pituitary hormones. Five of the samples stained positive for epithelial membrane antigen. The average MIB-1 index was 8.3\% (range 2-17). Postoperatively, 3 of the 6 patients received further treatment for progression of residual tumor or for recurrence, 2 have stable residual tumor, and 1 has had no recurrence after gross-total resection. Two patients developed postoperative complications of transient sixth cranial nerve palsy and diplopia. There were no other complications.

CONCLUSIONS SCO poses both a diagnostic and therapeutic challenge. These tumors are often initially misdiagnosed as nonfunctional pituitary adenomas because of their sellar location and nonspecific symptomatology. Postoperatively, SCO must also be distinguished from other neoplasms of the posterior pituitary gland through histopathological examination. Resection of SCO can be challenging, given its highly vascular and adherent nature. Long-term follow-up is critical, as the tumor is associated with higher recurrence and progression rates compared to other benign neoplasms of the sella.

https://thejns.org/doi/abs/10.3171/2018.4.JNS18211

KEYWORDS spindle cell oncocytoma; neurosurgery; transsphenoidal; pituitary surgery

$\mathrm{S}$ PINDLE cell oncocytomas (SCOs) are non-neuroendocrine neoplasms of the pituitary gland. Spindle cell oncocytoma was first included in the World Health Organization (WHO) classification of central nervous system (CNS) tumors in 2007 after the tumor was described in 2002.12,18,29 Roncaroli et al. defined SCO as spindled in appearance, with eosinophilic cytoplasm and numerous swollen mitochondria, immunoreactivity for vimentin, epithelial membrane antigen (EMA), galectin-3, and S100, no expression of pituitary hormones, and a benign histopathology due to lack of invasiveness and low proliferative activity. ${ }^{29}$

Clinically, SCOs are extremely rare. In a 7-year series of transsphenoidal (TS) operations at a single tertiary care

ABBREVIATIONS $C N=$ cranial nerve; $C N S$ = central nervous system; EMA = epithelial membrane antigen; GFAP = glial fibrillary acidic protein; GTR = gross-total resection; $\mathrm{OSH}=$ outside hospital; $\mathrm{SCO}=$ spindle cell oncocytoma; $\mathrm{S} 100=\mathrm{S} 100$ protein; $\mathrm{TS}=$ transsphenoidal; TTF $-1=$ thyroid transcription factor 1 ; WHO = World Health Organization.

SUBMITTED January 23, 2018. ACCEPTED April 27, 2018.

INCLUDE WHEN CITING Published online October 19, 2018; DOI: 10.3171/2018.4.JNS18211. 
TABLE 1. Presenting characteristics of the 6 SCO cases treated at our institutions

\begin{tabular}{|c|c|c|c|c|c|c|c|}
\hline $\begin{array}{l}\text { Case } \\
\text { No. }\end{array}$ & $\begin{array}{l}\text { Age } \\
\text { (yrs), } \\
\text { Sex }\end{array}$ & Presenting Sx & $\begin{array}{l}\text { Primary, } \\
\text { Recurrence, or } \\
\text { Progression }\end{array}$ & Size $(\mathrm{cm})$ & Tx & Intraop Events & Outcome/Subsequent Tx \\
\hline $1^{*}$ & $66, F$ & $\begin{array}{l}\text { Dizziness, nausea, } \\
\text { diaphoresis }\end{array}$ & Primary & $\begin{array}{l}1.7 \times 2.1 \times 2.4(\text { inf }) \\
1.5 \times 1.0 \times 1.3(\text { sup })\end{array}$ & TSR & & $\begin{array}{l}\text { Mild CN VI palsy resolved w/ dexameth; } \\
\text { stable residual tumor ( } 100 \text { mos) }\end{array}$ \\
\hline $2^{*}$ & $50, M$ & Dizziness & Primary & $1.2 \times 1.4 \times 1.3$ & TSR & $\begin{array}{l}\text { Signif intraop ve- } \\
\text { nous bleeding }\end{array}$ & Stable residual tumor (30 mos) \\
\hline $3^{*}$ & $63, \mathrm{M}$ & VD & $\begin{array}{l}\text { Progression ( } 3 \text { mos } \\
\text { postop from cra- } \\
\text { niotomy at } \mathrm{OSH})\end{array}$ & $2.7 \times 2.7 \times 1.9$ & TSR & & $\begin{array}{l}\text { Repeat TSR for tumor progression ( } 3 \\
\text { mos postop); craniotomy for tumor } \\
\text { progression ( } 42 \text { mos after repeat TSR) }\end{array}$ \\
\hline 4 & $59, \mathrm{~F}$ & $\begin{array}{l}\text { HA, thyroid \& } \\
\text { adrenal hypopit, } \\
\text { VD }\end{array}$ & $\begin{array}{l}\text { Primary (transferred } \\
\text { from an OSH } \\
\text { due to intraop } \\
\text { bleeding during } \\
\text { craniotomy) }\end{array}$ & & TSR & $\begin{array}{l}\text { Excessive intraop } \\
\text { bleeding }\end{array}$ & $\begin{array}{l}\text { Recurrence } 6 \text { yrs after GTR, treated w/ } \\
\text { repeat TSR, GKRS; stable (79 mos } \\
\text { after initial presentation) }\end{array}$ \\
\hline 5 & $77, \mathrm{M}$ & VD & Primary & $2.4 \times 2.8 \times 2.2$ & TSR & & Stable after GTR (12 mos) \\
\hline 6 & $56, \mathrm{~F}$ & $\begin{array}{l}\text { Eyeball heaviness, } \\
\text { nausea, dizzi- } \\
\text { ness }\end{array}$ & $\begin{array}{l}\text { Progression }(8.5 \\
\text { yrs after } 2 \text { TSRs, } \\
1 \text { craniotomy, } \\
\text { CKRS at OSH) }\end{array}$ & $3.8 \times 4.2 \times 4.1$ & TSR & & $\begin{array}{l}\text { Diplopia resolved } 1 \text { mo postop; proton } \\
\text { beam therapy for residual tumor; } \\
\text { stable residual tumor ( } 38 \text { mos after } \\
\text { initial op at our institution) }\end{array}$ \\
\hline
\end{tabular}

CKRS = CyberKnife radiosurgery; $\mathrm{CN}$ = cranial nerve; dexameth = dexamethasone; GKRS = Gamma Knife radiosurgery; HA = headache; hypopit = hypopituitarism; inf = inferior; $\mathrm{OSH}=$ outside hospital; signif = significant; sup = superior; $\mathrm{Sx}=$ symptoms; $\mathrm{TSR}$ = transsphenoidal resection; $\mathrm{Tx}=$ treatment; VD = visual deficit.

${ }^{*}$ These cases were previously reported with limited clinical detail in a study of SCO exome profiles. ${ }^{23}$

center, SCO accounted for $0.51 \%$ of final pathological diagnoses among nearly 800 transnasal, TS operations. ${ }^{6}$ In reviewing the literature from 2002 to 2018, approximately 40 cases of SCO have been reported. Because of their similarity on imaging to other pituitary neoplasms and nonfunctional hormonal status, SCOs are frequently misdiagnosed preoperatively, often as nonfunctional pituitary adenomas. ${ }^{26}$ Historically, there has been much debate about the origin of and intersection among SCO, pituicytoma, and granular cell tumors, all of which share similar histopathological features. ${ }^{7,16,22,36}$ In the fourth edition of the WHO classification of tumors of the endocrine glands, pituitary $\mathrm{SCO}$-along with pituicytoma, granular cell tumor of the sella, and sellar ependymoma-was classified as a tumor of the posterior pituitary. ${ }^{17}$ Previously, SCOs were thought to arise from the adenohypophysis. ${ }^{29}$ There is support for the idea that these tumors, which remain classified as distinct tumor subtypes, may be variations of the same pathophysiology and may arise from a common progenitor cell in the posterior pituitary, the pituicyte. ${ }^{17,21}$

We describe the presentation, management, pathological characteristics, and outcomes of 6 cases with longterm follow-up. In doing so, we aim to advance the clinical understanding of these lesions, as their diagnosis and management is often difficult and complex.

\section{Methods}

We retrospectively reviewed cases in which patients underwent resection of pituitary lesions performed by the senior authors at 2 large academic centers between January 2000 and October 2017. We identified patients who had histopathological confirmation of SCO. Three of the cases included have been previously published in a study on the molecular etiology of SCO. ${ }^{23}$ In the present study, we add additional neurosurgical context and long-term follow-up information for these cases. The formal histological diagnosis was characterized by spindled cellular appearance with eosinophilic cytoplasm and immunoreactivity for glial fibrillary acidic protein (GFAP), S100, thyroid transcription factor 1 (TTF-1), EMA, and pituitary hormones. We collected clinical data, including preoperative, perioperative, and postoperative management, complications, and outcomes.

\section{Results}

Six patients were diagnosed with SCO over a 17-year period (Table 1). Of the 6 patients, 3 were women and 3 were men; the patients' mean age was 62 years (range 50-77 years).

Three patients (cases 1,2, and 5) presented to our institutions with newly diagnosed sellar masses and recentonset symptoms that included dizziness, nausea, and diaphoresis (case 1); dizziness (case 2); and visual disturbances, including temporal field loss and afferent pupillary defects (case 5). All 3 patients underwent TS operations. Gross-total resection (GTR) was achieved in case 5 , with no evidence of residual or recurrent tumor at 12 months postoperatively. The patients in cases 1 and 2 both had residual tumor on postoperative MRI that has been stable at 100 and 30 months postoperatively, respectively (Fig. 1A, B, D, and E). Intraoperatively, significant venous bleeding was noted in case 2 , but no postoperative deficits were present. The patient in case 1 developed cranial nerve $(\mathrm{CN})$ VI palsy, which resolved with a 10-day course 


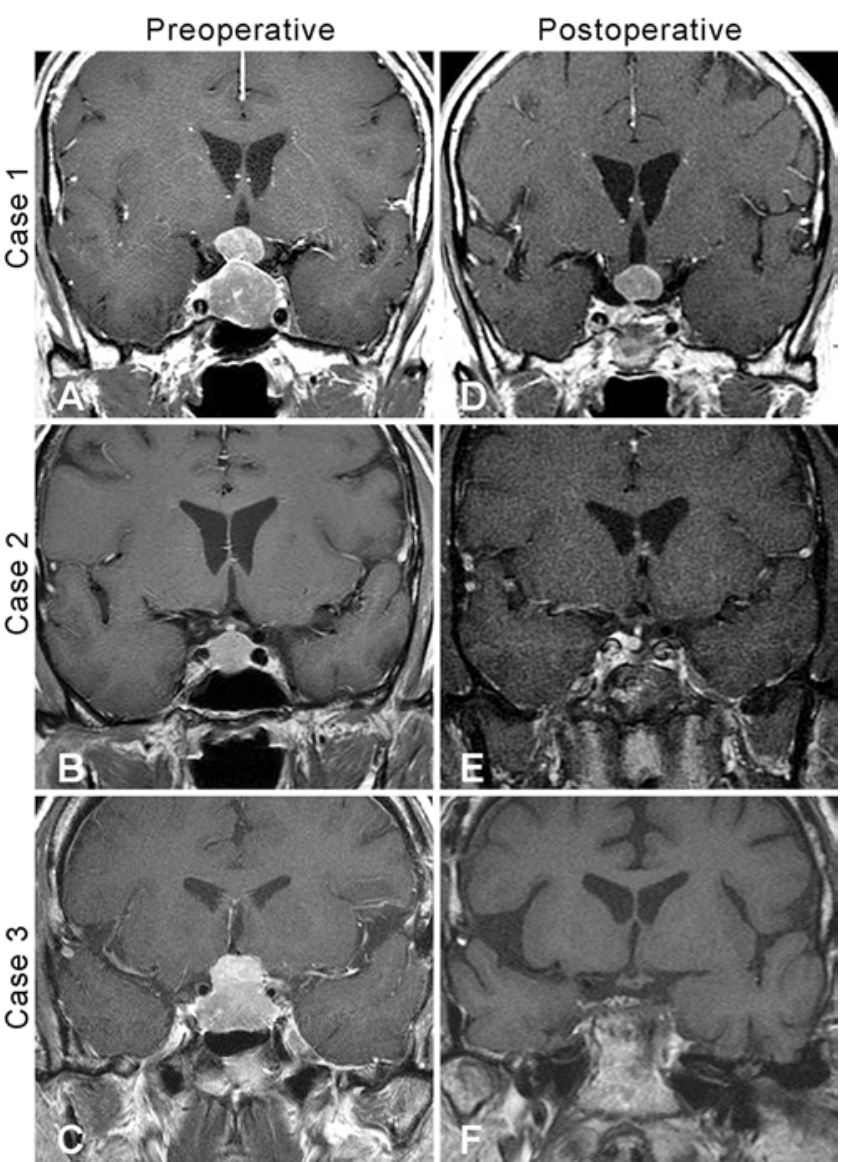

FIG. 1. Preoperative and postoperative coronal contrast-enhanced T1-weighted MR images. A: Preoperative image showing a dumbbellshaped intrasellar and suprasellar SCO (case 1). B: Preoperative image showing an intrasellar tumor that was initially misdiagnosed as a pituitary adenoma (case 2). C: Preoperative image of a SCO obtained after a craniotomy at an OSH (case 3). D: Follow-up image obtained 100 months postoperatively showing stable residual tumor (case 1). E: Follow-up image obtained 30 months postoperatively showing stable residual tumor (case 2). F: Postoperative MR image showing residual after 2 transsphenoidal resections and 2 craniotomies (case 3 ).

of dexamethasone. There were no other surgical complications in these 3 cases. The presenting symptoms of all 3 patients improved with surgery.

The other 3 patients (cases 3, 4, and 6) had prior resection of tumor involving the pituitary region at outside hospitals (OSHs) before presentation. All patients eventually underwent TS resection at one of the 2 centers included in this study. The patient in case 3 presented to our institution 3 months after undergoing craniotomy at an OSH for tumor progression. He initially presented to the OSH and to our institution with visual disturbance. The patient underwent 2 subtotal TS resections and a craniotomy for tumor progression 3 months, 6 months, and 4 years after initial resection at the OSH (Fig. 1C and F). Because of the craniotomy was performed only recently, no follow-up information is available. The patient's vision did not improve. The patient in case 4 was transferred to our institution after an aborted craniotomy due to excessive hemorrhage during the operation. A TS operation was performed with no evidence of residual tumor on postoperative MRI. The

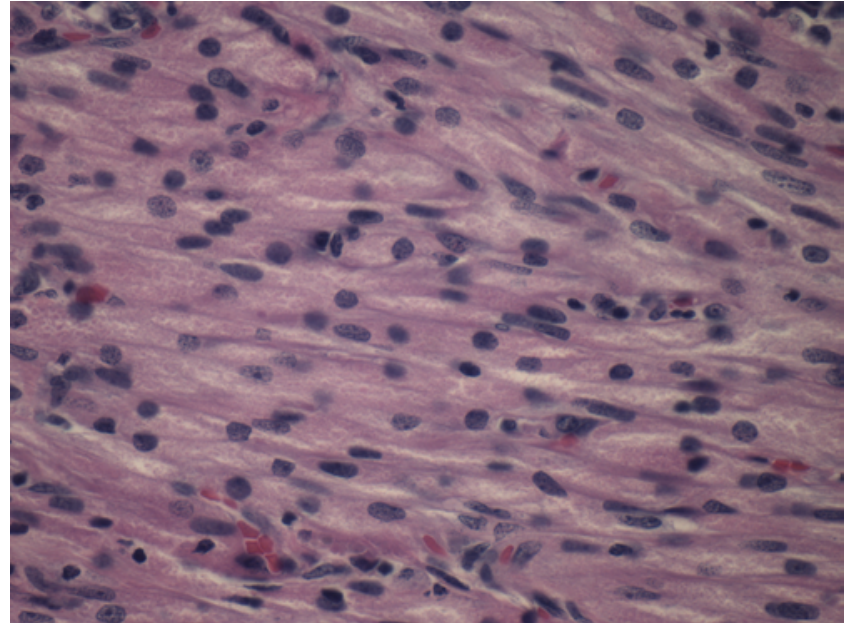

FIG. 2. Photomicrograph of SCO (case 1). H \& E; original magnification $\times 600$. Figure is available in color online only.

patient's visual disturbances, cranial nerve palsy, diplopia, and headache improved after TS resection. Six years later, the tumor recurred, with symptoms of left sided cranioorbital pain and left CN VI palsy. The patient underwent repeat TS resection and Gamma Knife radiosurgery. The residual tumor is currently stable 79 months after initial presentation; she has persistent left-sided headache but her diplopia and left CN VI palsy have both resolved. The patient in case 6 presented to our institution 9 years after undergoing 2 TS resections, one craniotomy, and CyberKnife therapy at an OSH. She presented with eyeball heaviness, nausea, and dizziness. She underwent TS resection and received proton beam therapy for enlarging residual tumor. The patient developed diplopia that resolved 1 month after the operation, and the residual tumor is currently stable 38 months postoperatively.

On pathological examination, SCO was diagnosed by spindled cellular appearance with abundant granular eosinophilic cytoplasm (Fig. 2) in all 6 cases. All samples stained positive for S100 and TTF-1 (Fig. 3) and negative for GFAP and pituitary hormones (Table 2). Five of the 6 samples stained positive for EMA. No necrosis or increased mitotic activity was seen in any of the cases. The mean MIB-1 index was 8.3\% (median 5.5, range 2-17).

\section{Discussion}

SCO is a rare and often misdiagnosed neoplasm of the posterior pituitary. SCOs generally arise in the region of the sella and present similarly to nonfunctional pituitary adenomas, making it difficult to distinguish them from other common pituitary lesions based on imaging alone. ${ }^{24,26}$ Preoperative symptoms are not diagnostic, as common symptoms of SCO, including visual disturbances, headache, and hypopituitarism, are nonspecific results of mass effect on parasellar structures. SCOs have no immunoreactivity for pituitary hormones, nor neuroendocrine markers such as chromogranin and synaptophysin. ${ }^{22,29}$ The tumors have a distinctive microscopic appearance, however, with spindled cells containing granular eosinophilic cytoplasm, and a distinct immunohistochemical 


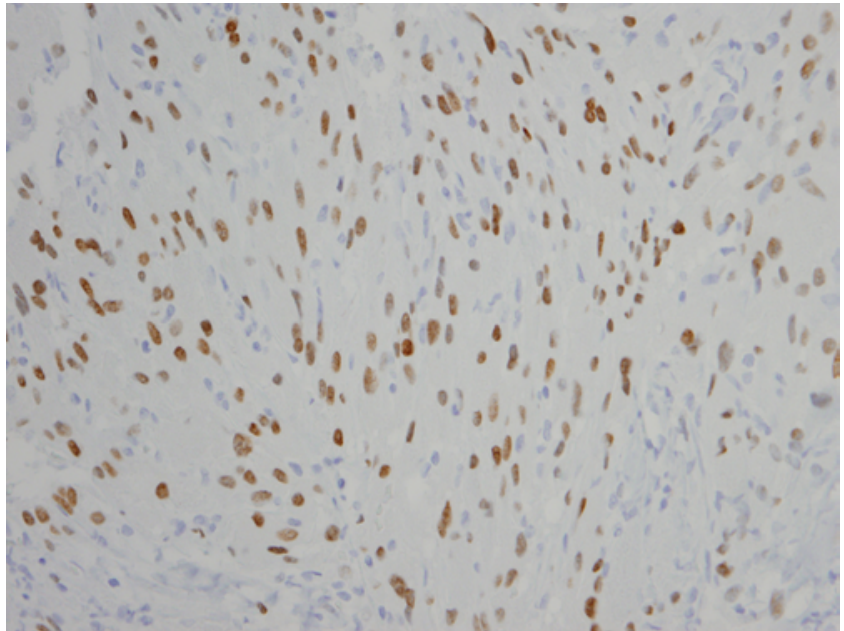

FIG. 3. Photomicrograph of SCO, stained by immunohistochemistry for TTF-1 (NKX2-1). Original magnification $\times 400$ (case 2). Figure is available in color online only.

profile that distinguishes them from adenomas on pathological examination.

In this paper, we present 6 cases of SCO treated at 2 multidisciplinary pituitary centers in an effort to discuss contemporary management of these complex lesions. Prior to this study, the largest series of SCOs in the literature was reported in the seminal paper of Roncaroli et al. in 2002, which included 5 patients, and defined the novel neoplasm "spindle cell oncocytoma." ${ }^{29}$ In 2007, the WHO included SCO in the classification of CNS tumors as a distinct non-neuroendocrine lesion.

Not including the cases reported in this paper (or the subset reported earlier by Miller et al. ${ }^{23}$ ), a total of 39 cases of SCO have been reported in the literature as case reports and case series (Table 3)..$^{1-5,8-11,13-15,19,20,23-36}$ These lesions are often initially managed by a TS approach because preoperative radiological features are suggestive of a pituitary adenoma. ${ }^{26}$ Of 37 cases for which type of resective surgery was reported in the literature, $32(86.5 \%)$ were managed initially with TS resection and $5(13.5 \%)$ were managed initially with craniotomy. In the current case series, the senior authors performed TS resection on all 6 patients. However, 3 patients had undergone prior craniotomy.

SCO has a significant risk of progression or recurrence. Because of the vascular and adherent nature of the tumor, subtotal resection of SCO is common. Gross-total resection (GTR) was achieved in only 2 of the cases presented here, and in one of those 2 cases, the tumor subsequently recurred. Of the 41 cases with follow-up information, including our own, $39 \%$ were recurrent at the time of surgery, recurred postoperatively after GTR, or required additional surgery for residual tumor. The progression and recurrence rate of this tumor may be higher than reported given variable follow-up durations. There are 8 reports in the literature of individuals receiving radiation after resection.

These high rates of recurrence, reoperation, and adjuvant radiation suggest a more clinically aggressive course for SCO compared to other lesions of the sellar region. The 6 cases reported here also fit this pattern: only 3 were managed successfully with a single TS operation (mean follow-up 47 months). The remaining 3 lesions required the following additional interventions: a prior craniotomy at an $\mathrm{OSH}$, a reoperation by the TS approach (the same year the patient presented), and a craniotomy for recurrence; a TS reoperation followed by Gamma Knife radiosurgery; and 2 TS operations, reoperation by craniotomy, and CyberKnife at an OSH prior to resection and proton beam radiotherapy after resection at our institution.

In a summary of the 2017 WHO classification of tumors of endocrine glands, Lopes reviewed the features of tumors of the posterior pituitary, including granular cell tumor, SCO, pituicytoma, and sellar ependymoma. ${ }^{17}$ These tumors remain classified as distinct tumor entities in the new classification scheme. It is believed, however, that the tumors may be subtypes that arise from a common progenitor cell of the posterior pituitary, the pituicyte, and are variations of the same pathophysiology (Table 4). Strong staining for EMA would support a histological diagnosis of SCO. In our series, the tumors were EMA-positive in 5 of 6 cases. The SCO in case 3 was initially EMA-negative but had focal EMA positivity on subsequent resection and pathological analysis. ${ }^{23}$ Equivocal or negative EMA staining could indicate that this tumor is another variation of a pituitary gland tumor or that the sample was not representative of the tumor's true characteristics. As seen in the literature review of immunohistochemical markers, including in our own samples, SCO is generally reactive for S100 (93\% of samples tested), EMA (95\%), and TTF-1 $(100 \%)$, and only rarely reactive for GFAP $(10.8 \%)$ (Table 2). Although Roncaroli et al. noted the benign nature of SCO with a low proliferative index, we have demonstrated this is not exclusively the case. Along with the high rates of recurrence and progression of the tumor, it is demonstrated in the literature review and in our own cases that $\mathrm{SCO}$ can have a high proliferative index measured by MIB-1/Ki-67 index. In 2 of our cases, the MIB-1 index was above $10 \%$.

Of note, SCOs are highly vascular tumors that can cause significant intraoperative bleeding. ${ }^{17}$ Borges et al. report a case of recurrent subclinical intratumoral bleeding occurring in a recurrent $\mathrm{SCO} .{ }^{3} \mathrm{In}$ a review of the literature within this paper, Borges found that $29 \%$ of 28 case reports reviewed noted excessive intraoperative bleeding and $46 \%$ of cases noted the tumor to be highly vascular intraoperatively. There were also 3 cases of spontaneous tumor hemorrhage. In the cases that we present in the present study, 2 patients were noted to have more than a normal amount of intraoperative bleeding, and one of the two was transferred from an OSH after excessive intraoperative bleeding during the initial resection. Careful attention must be paid to the potential for significant intraoperative bleeding when dealing with a tumor of the posterior pituitary gland, especially SCO.

On molecular analysis, recent reports have identified novel mutations in SCO tumors, including co-occurring somatic $H R A S$-activating mutations and MEN1 frameshift mutations, which may contribute to their clinical aggressiveness. ${ }^{23}$ As a result of the particularly aggressive nature of these lesions, patients who harbor SCO should receive frequent postoperative radiographic and clinical monitor- 
TABLE 2. Pathological characteristics of SCO cases reported in the literature

\begin{tabular}{|c|c|c|c|c|c|c|c|}
\hline Authors \& Year & Necrosis & Mitosis & MIB-1/Ki-67 Index (\%) & EMA & TTF-1 & $S 100$ & GFAP \\
\hline \multirow[t]{5}{*}{ Roncaroli et al., 2002} & Absent & Absent & 1 & + & NA & + & - \\
\hline & Absent & Absent & 3 & + & NA & + & - \\
\hline & Focal & Rare & 1 & + & NA & - & - \\
\hline & Absent & Absent & 3 & + (rare) & NA & + & - \\
\hline & Absent & Rare & 5 & + & NA & + & - \\
\hline \multirow[t]{2}{*}{ Kloub et al., 2005} & Absent & Absent & 18 & + & NA & + & - \\
\hline & Focal & Increased & 20 & + & NA & + & - \\
\hline \multirow[t]{2}{*}{ Dahiya et al., 2005} & Absent & Absent & 1 & + & NA & + & - \\
\hline & Absent & Absent & 8 & + & NA & + & - \\
\hline Vajtai et al., 2006 & Absent & Absent & $<1$ & + & NA & + & $+($ few $)$ \\
\hline Coiré et al., 2009 & NA & NA & NA & NA & NA & NA & NA \\
\hline Borota et al., 2009 & NA & NA & NA & + & NA & + & NA \\
\hline \multirow[t]{2}{*}{ Matyja et al., 2010} & Absent & Rare & 5 & + & NA & + & - \\
\hline & Absent & Rare & 1 & + & NA & + & - \\
\hline Demssie et al., 2011 & Absent & Absent & $<1$ & + & NA & + & NA \\
\hline Vajtai et al., 2011 & Absent & Absent & $1.5-2$ & + & + & + & - \\
\hline Mlika et al., 2011 & Absent & Low & NA & + & + & + & - \\
\hline Romero-Rojas et al., 2011 & NA & Low & 2 & + & NA & + & - \\
\hline Borges et al., 2011 & Absent & Low & 3.2 & + (rare) & NA & + & - \\
\hline Ogiwara et al., 2011 & Absent & Rare & 5 & + & + & + & NA \\
\hline Singh et al., 2012 & Absent & Absent & $<1$ & + & NA & + & - \\
\hline Alexandrescu et al., 2012 & Absent & Absent & $<5$ & + & NA & + & - \\
\hline Fujisawa et al., 2012 & Absent & Absent & 3 & + & NA & + & - \\
\hline Rotman et al., 2014 & NA & Absent & 2.5 & + & NA & - & - \\
\hline \multirow[t]{2}{*}{ Mu et al., 2015} & NA & Absent & 3 & + & + & + & - \\
\hline & NA & Absent & 1.5 & + & + & + & - \\
\hline \multirow[t]{2}{*}{ Zygourakis et al., 2015} & NA & NA & $<5$ & + & + & - & - \\
\hline & NA & NA & NA & + & + & + & + \\
\hline Custodio et al., 2016 & NA & NA & 3 & + & + & + & - \\
\hline \multirow[t]{3}{*}{ Hasiloglu et al., 2016} & Absent & Absent & NA & + & NA & + & NA \\
\hline & Absent & Absent & NA & + & NA & + & NA \\
\hline & Absent & Absent & NA & + & NA & + & NA \\
\hline Vuong et al., 2016 & Absent & Absent & $<1$ & + & + & + & NA \\
\hline Guadagno et al., 2016 & Absent & Absent & 11 & + & + & + & - \\
\hline \multirow[t]{2}{*}{ Billeci et al., 2017} & Absent & Absent & 2 & NA & + & + & - \\
\hline & Absent & Low & 8 & NA & + & + & - \\
\hline Osman \& Wild, 2017 & Absent & Absent & Low & + & + & + & + \\
\hline Manoranjan et al., 2017 & Absent & Absent & $2-4$ & - & + & + & + \\
\hline Sali et al., 2017 & Absent & Absent & $6-8$ & + & + & + & - \\
\hline Current study, case $1^{*}$ & Absent & Absent & 5 & + & + & + & - \\
\hline Case $2^{*}$ & Absent & Absent & 2 & + & + & + & - \\
\hline Case $3^{*}$ & Absent & Absent & 5 & - & + & + & - \\
\hline Case 4 & Absent & Absent & 15 & + & + & + & - \\
\hline Case 5 & Absent & Absent & 6 & + & + & + & - \\
\hline Case 6 & Absent & Absent & 17 & + & + & + & - \\
\hline
\end{tabular}


TABLE 3. Literature review of SCO cases

\begin{tabular}{|c|c|c|c|c|c|c|}
\hline $\begin{array}{l}\text { Authors } \\
\& \text { Year }\end{array}$ & $\begin{array}{l}\text { Age (yrs), } \\
\text { Sex }\end{array}$ & $\begin{array}{l}\text { Presenting } \\
\text { Sx }\end{array}$ & $\begin{array}{c}\text { Primary or } \\
\text { Progression/Recurrence }\end{array}$ & $\begin{array}{l}\text { Size } \\
(\mathrm{cm})\end{array}$ & Tx & $\begin{array}{c}\text { Outcome/Subsequent } \\
\text { Tx }\end{array}$ \\
\hline \multirow{5}{*}{$\begin{array}{l}\text { Roncaroli et al., } \\
\quad 2002\end{array}$} & \multirow{5}{*}{$\begin{array}{c}\text { 53-71 } \\
\text { (mean 61.6); } \\
\text { 2F, 3M }\end{array}$} & PHP & Primary & NA & TSR & \multirow{5}{*}{$\begin{array}{l}\text { FU 2-68 mos (mean } 35.4 \\
\text { mos); no recurrences } \\
\text { noted }\end{array}$} \\
\hline & & PHP & Primary & NA & TSR & \\
\hline & & PHP & Primary & NA & TSR & \\
\hline & & PHP, VD & Primary & NA & TSR & \\
\hline & & PHP, VD & Primary & NA & Craniotomy & \\
\hline \multirow[t]{2}{*}{ Kloub et al., 2005} & $71, \mathrm{~F}$ & VD, PHP (mild) & $\begin{array}{l}\text { P/R: primary TSR } 11 \text { yrs } \\
\text { prior; 1st sign of recur- } \\
\text { rence } 8 \text { yrs prior }\end{array}$ & NA & TSR & $\begin{array}{l}\text { Add'l resection for } \\
\text { residual tumor } 1 \mathrm{yr} \\
\text { postop }\end{array}$ \\
\hline & $76, \mathrm{M}$ & Epistaxis & $\begin{array}{l}\text { P/R: primary TSR } 10 \text { yrs } \\
\text { prior w/ add'I resection \& } \\
\text { radiation } 7 \text { yrs prior }\end{array}$ & NA & TSR & NA \\
\hline \multirow[t]{2}{*}{ Dahiya et al., 2005} & $26, M$ & $\begin{array}{r}\mathrm{HA}, \mathrm{VD}, \mathrm{N} / \mathrm{V} \\
\text { impotence }\end{array}$ & Primary & $1.5-2$ (diam) & $\begin{array}{l}\text { TSR, craniotomy, } \\
\text { proton beam } \\
\text { radiation }\end{array}$ & Stable (7 yrs) \\
\hline & $55, \mathrm{~F}$ & HA, VD & Primary & $6.5 \times 3.3 \times 4.0$ & TSR & Stable (6 mos) \\
\hline Vajtai et al., 2006 & $48, \mathrm{~F}$ & Fatigue, VD & Primary & $1.8 \times 1.5 \times 1.3$ & TSR & Stable (16 yrs) \\
\hline Coiré et al., 2009 & NA & NA & Primary & NA & TSR & $\begin{array}{l}\text { Add'l TSR \& radiation } 5 \\
\text { mos postop }\end{array}$ \\
\hline Borota et al., 2009 & NA & NA & NA & NA & TSR, RT & $\begin{array}{l}\text { Regrowth over } 30-\text { mo FU } \\
\text { period }\end{array}$ \\
\hline \multirow[t]{2}{*}{ Matyja et al., 2010} & $63, \mathrm{~F}$ & PHP, N/V, HA, VD & Primary & $2.1 \times 1.8 \times 1.9$ & TSR & Stable (28 mos) \\
\hline & $65, \mathrm{~F}$ & PHP & P/R: primary TSR 3 yrs prior & $1.8 \times 1.9 \times 2.1$ & Frontal craniotomy & Stable (20 mos) \\
\hline $\begin{array}{l}\text { Demssie et al., } \\
2011\end{array}$ & $59, \mathrm{M}$ & PHP, VD, N/V & Primary & NA & TSR, RT & 2 add'I TSR 9 mos postop \\
\hline Vajtai et al., 2011 & $55, \mathrm{~F}$ & PHP & Primary & $2.7 \times 2.6 \times 2.5$ & TSR & \\
\hline Mlika et al., 2011 & $45, \mathrm{~F}$ & VD, HA & Primary & $2.0 \times 1.5 \times 1.0$ & TSR & Stable (3 mos) \\
\hline $\begin{array}{l}\text { Romero-Rojas et } \\
\quad \text { al., } 2011\end{array}$ & $42, \mathrm{~F}$ & Oligomenorrhea & Primary & $3.2 \times 3.2 \times 3.4$ & "Resection" & NA \\
\hline Borges et al., 2011 & $70, \mathrm{~F}$ & VD & Primary & $3.3 \times 2.4 \times 3.0$ & TSR & $\begin{array}{l}\text { Recurrence \& add'I TSR } \\
13 \text { yrs postop }\end{array}$ \\
\hline $\begin{array}{l}\text { Ogiwara et al., } \\
2011\end{array}$ & $39, M$ & HA, memory loss & $\begin{array}{l}\text { P/R: primary craniotomy \& } \\
\text { radiation } 13 \text { mos prior; } \\
\text { add'l resection } 4 \text { mos } \\
\text { prior w/ residual }\end{array}$ & $2.7 \times 2.4 \times 2.8$ & TSR & Stable residual (1 yr) \\
\hline Singh et al., 2012 & $68, M$ & $\mathrm{VD}, \mathrm{HA}$ & Primary & $3.1 \times 2.9 \times 3.0$ & TSR & $\begin{array}{l}\text { Died from unrelated } \\
\text { causes } 1 \text { mo postop }\end{array}$ \\
\hline $\begin{array}{l}\text { Alexandrescu et } \\
\text { al., } 2012\end{array}$ & $24, \mathrm{~F}$ & $\begin{array}{l}\text { HA, amenorrhea, } \\
\text { VD }\end{array}$ & Primary & $2.5 \times 1.8$ & TSR & Stable (6 mos) \\
\hline $\begin{array}{l}\text { Fujisawa et al., } \\
2012\end{array}$ & $68, M$ & PHP, VD & Primary & NA & TSR & $\begin{array}{l}\text { Transcranial re-resection } \\
\quad \text { for residual tumor \& ra- } \\
\text { diation } 18 \text { mos postop }\end{array}$ \\
\hline Rotman et al., 2014 & $88, M$ & PHP, VD, fatigue & Primary & $2.7 \times 2.0 \times 1.7$ & TSR & NA \\
\hline \multirow[t]{2}{*}{ Mu et al., 2015} & $35, F$ & $\begin{array}{l}\text { Amenorrhea, } \\
\text { lactation, VD }\end{array}$ & Primary & $2.5 \times 3.0 \times 1.0$ & Craniotomy & Stable (21 mos) \\
\hline & $62, \mathrm{~F}$ & Incidental finding & Primary & $2.3 \times 1.7 \times 2.0$ & Craniotomy & Stable (15 mos) \\
\hline \multirow{2}{*}{$\begin{array}{l}\text { Zygourakis et al., } \\
2015\end{array}$} & $31, \mathrm{~F}$ & $\mathrm{VD}, \mathrm{HA}$ & Primary & 2.2 (diam) & TSR & Stable (6 mos) \\
\hline & $53, \mathrm{~F}$ & $\mathrm{HA}$ & Primary & 0.7 (diam) & Biopsy & Stable (2 mos) \\
\hline $\begin{array}{l}\text { Custodio et al., } \\
2016\end{array}$ & $60, \mathrm{M}$ & $\begin{array}{l}\text { N/V, syncope, } \\
\text { PHP, hypona- } \\
\text { tremia }\end{array}$ & Primary & $3.1 \times 2.3 \times 2.0$ & TSR & Stable (18 mos) \\
\hline
\end{tabular}


» CONTINUED FROM PAGE 522

TABLE 3. Literature review of SCO cases

\begin{tabular}{|c|c|c|c|c|c|c|}
\hline $\begin{array}{l}\text { Authors } \\
\& \text { Year }\end{array}$ & $\begin{array}{l}\text { Age (yrs), } \\
\text { Sex }\end{array}$ & $\begin{array}{l}\text { Presenting } \\
\text { Sx }\end{array}$ & $\begin{array}{c}\text { Primary or } \\
\text { Progression/Recurrence }\end{array}$ & $\begin{array}{l}\text { Size } \\
(\mathrm{cm})\end{array}$ & Tx & $\begin{array}{c}\text { Outcome/Subsequent } \\
\text { Tx }\end{array}$ \\
\hline \multirow[t]{3}{*}{$\begin{array}{l}\text { Hasiloglu et al., } \\
\quad 2016\end{array}$} & $40, M$ & PHP & Primary & $2.1 \times 1.9 \times 3.6$ & TSR & $\begin{array}{l}\text { Add'I TSR } 1 \text { yr postop for } \\
\text { residual tumor }\end{array}$ \\
\hline & $60, M$ & $H A, V D$ & Primary & $3.1 \times 2.0 \times 2.3$ & TSR & Stable (12 mos) \\
\hline & $55, \mathrm{M}$ & $H A, V D$ & Primary & $2.0 \times 1.9 \times 1.8$ & TSR & Stable (6 mos) \\
\hline Vuong et al., 2016 & $70, \mathrm{M}$ & $H A, V D$ & Primary & $6.0 \times 5.5 \times 4.5$ & TSR & Stable (6 mos) \\
\hline $\begin{array}{l}\text { Guadagno et al., } \\
2016\end{array}$ & $77, \mathrm{M}$ & $H A, V D$ & Primary & & TSR & Stable (14 mos) \\
\hline \multirow[t]{2}{*}{ Billeci et al., 2017} & $61, M$ & $\mathrm{HA}$ & Primary & $2.2 \times 1.8 \times 2.7$ & TSR & $\begin{array}{l}\text { Add'I TSR for residual } \\
\text { tumor } 16 \text { mos postop; } \\
\text { stable (14 mos) }\end{array}$ \\
\hline & $65, F$ & $H A, V D$ & Primary & $2.0 \times 1.5 \times 1.0$ & TSR & Stable (28 mos) \\
\hline $\begin{array}{l}\text { Osman \& Wild, } \\
2017\end{array}$ & $56, \mathrm{M}$ & $\begin{array}{l}\text { HA, altered LOC, } \\
\text { VD }\end{array}$ & Primary & $2.5 \times 4.4 \times 2.5$ & $\begin{array}{l}\text { Craniotomy } \\
\text { (urgent), EVD }\end{array}$ & Stable (6 mos) \\
\hline $\begin{array}{l}\text { Manoranjan et al., } \\
2017\end{array}$ & $60, \mathrm{M}$ & VD & $\begin{array}{l}\text { P/R: primary resection } 13 \\
\text { yrs prior; biopsy \& RT for } \\
\text { residual tumor } 11 \text { yrs prior }\end{array}$ & $2.6 \times 3.0 \times 2.4$ & TSR & Stable (9 mos) \\
\hline Sali et al., 2017 & $64, \mathrm{M}$ & VD & P/R: primary TSR 4 yrs prior & $2.2 \times 2.1 \times 2.5$ & TSR & NA \\
\hline
\end{tabular}

Add'I = additional; diam = diameter; EVD = external ventricular drain; FU = follow-up; LOC = level of consciousness; N/V = nausea/vomiting; PHP = panhypopituitarism; $\mathrm{P} / \mathrm{R}=$ progression/recurrence; $\mathrm{RT}$ = radiotherapy; $\mathrm{TSR}$ = transsphenoidal resection; $\mathrm{VD}=$ visual deficit.

The 6 cases reported in the current study (including the 3 previously reported by Miller et al. ${ }^{23}$ ) are not included in this table. For a summary of those cases, please see Table 1.

ing. In most cases of sellar lesions, annual imaging is sufficient.

In cases of recurrent tumor or growth of residual tumor after subtotal resection, patients should seek multidisciplinary management, with consideration given to both reoperation and possible radiation therapy. In two of our cases (cases 4 and 6), progressive growth of residual tumor halted after adjuvant radiation.

There are also case reports of SCOs managed transcranially, which has been posited to be of benefit given their

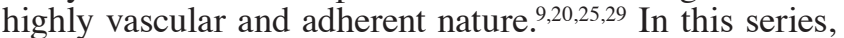
one operation at an OSH had to be aborted because of intraoperative bleeding during a standard craniotomy (case 4), and it is possible that the transcranial approach may provide more intraoperative maneuverability to deal with excessive bleeding and better access to adherent areas of tumor. Nevertheless, each of the 6 SCOs reported on here was ultimately managed by the TS approach. With proper adjuvant therapy and careful monitoring, SCO can be successfully treated transsphenoidally, and even in cases of subtotal resection, patients can experience substantial benefit due to relief of mass effect on the pituitary gland and optic chiasm.

The limitations of our study include the retrospective nature, relatively small sample size related to the rareness of the entity, and heterogeneous management of the 6 cases presented. However, we believe that our study, which is the largest case study of SCO to date, offers value by discussing current diagnostic, therapeutic, and management strategies. In addition, we thoroughly review the literature with

TABLE 4. TTF-1-positive tumors of the posterior pituitary gland

\begin{tabular}{|c|c|c|c|}
\hline $\begin{array}{l}\text { Tumor } \\
\text { Subtype }\end{array}$ & Histology \& Ultrastructure (EM) & Immunoreactivity & $\begin{array}{l}\text { Distinguishing } \\
\text { Features }\end{array}$ \\
\hline All & & $\begin{array}{l}\text { TTF-1 (strong nuclear immunoreactivity) }{ }^{16,22} \\
\text { S100 (variable staining) }\end{array}$ & \\
\hline SCO & $\begin{array}{l}\text { Spindle or epitheloid cells in intertwining fascicles w/ granulated } \\
\text { eosinophilic cytoplasm; abundant mitochondria by EM }\end{array}$ & $\begin{array}{l}\text { EMA (strong) } \\
\text { GFAP (rarely positive) }\end{array}$ & $\begin{array}{l}\text { Increased tendency to } \\
\text { bleed during the op }\end{array}$ \\
\hline Pituicytoma & $\begin{array}{l}\text { Fibrillary cells arranged in fascicles w/ elongated nuclei; abundant } \\
\text { intermediate filament processes by EM }\end{array}$ & $\begin{array}{l}\text { EMA (variable) } \\
\text { GFAP (positive generally) }\end{array}$ & \\
\hline $\begin{array}{l}\text { Granular cell } \\
\text { tumor }\end{array}$ & $\begin{array}{l}\text { Polygonal cells w/ central nuclei \& PAS-positive, granular cyto- } \\
\text { plasm; abundant lysosomes by EM }\end{array}$ & $\begin{array}{l}\text { EMA (variable) } \\
\text { GFAP (rarely positive) }\end{array}$ & \\
\hline
\end{tabular}

$\mathrm{EM}=$ electron microscopy; PAS = periodic acid-Schiff. 
a focus on the pathological characteristics of SCO in the context of the updated 2017 WHO classification of SCO.

\section{Conclusions}

SCO poses both a diagnostic and therapeutic challenge. Because of its sellar location and common presenting symptoms of visual disturbances, headache, and hypopituitarism, it is often misdiagnosed as a nonfunctional pituitary adenoma. Because of the highly vascular and adherent nature of these lesions, resection of SCO can be hazardous but even subtotal resection can interrupt progression and provide symptomatic relief. In addition, SCO is associated with a high recurrence and progression rate compared to other benign neoplasms of the sella, and vigilant long-term follow-up is recommended.

\section{Acknowledgments}

This study was partially funded by National Institutes of Health (NIH) Training Grant T32 CA 009001 (to DJC).

\section{References}

1. Alexandrescu S, Brown RE, Tandon N, Bhattacharjee MB: Neuron precursor features of spindle cell oncocytoma of adenohypophysis. Ann Clin Lab Sci 42:123-129, 2012

2. Billeci D, Marton E, Giordan E, Carraro V, Ronzon M, Rossi S: Spindle cell oncocytoma: report of two cases with massive bleeding and review of the literature. J Clin Neurosci 39:39-44, 2017

3. Borges MT, Lillehei KO, Kleinschmidt-DeMasters BK: Spindle cell oncocytoma with late recurrence and unique neuroimaging characteristics due to recurrent subclinical intratumoral bleeding. J Neurooncol 101:145-154, 2011

4. Borota OC, Scheithauer BW, Fougner SL, Hald JK, RammPettersen J, Bollerslev J: Spindle cell oncocytoma of the adenohypophysis: report of a case with marked cellular atypia and recurrence despite adjuvant treatment. Clin Neuropathol 28:91-95, 2009

5. Coiré CI, Horvath E, Smyth HS, Kovacs K: Rapidly recurring folliculostellate cell tumor of the adenohypophysis with the morphology of a spindle cell oncocytoma: case report with electron microscopic studies. Clin Neuropathol 28:303-308, 2009

6. Cote DJ, Wiemann R, Smith TR, Dunn IF, Al-Mefty O, Laws ER: The expanding spectrum of disease treated by the transnasal, transsphenoidal microscopic and endoscopic anterior skull base approach: a single-center experience 2008-2015. World Neurosurg 84:899-905, 2015

7. Covington MF, Chin SS, Osborn AG: Pituicytoma, spindle cell oncocytoma, and granular cell tumor: clarification and meta-analysis of the world literature since 1893. AJNR Am J Neuroradiol 32:2067-2072, 2011

8. Custodio PJP, Jho DH, Pu C, Gordon MB, Donangelo I: Spindle cell oncocytoma of the pituitary presenting with severe hyponatremia. AACE Clin Case Rep 2:e237-e243, 2016

9. Dahiya S, Sarkar C, Hedley-Whyte ET, Sharma MC, Zervas NT, Sridhar E, et al: Spindle cell oncocytoma of the adenohypophysis: report of two cases. Acta Neuropathol 110:97-99, 2005

10. Demssie YN, Joseph J, Dawson T, Roberts G, de Carpentier J, Howell S: Recurrent spindle cell oncocytoma of the pituitary, a case report and review of literature. Pituitary 14:367-370, 2011

11. Fujisawa H, Tohma Y, Muramatsu N, Kida S, Kaizaki Y, Tamamura H: Spindle cell oncocytoma of the adenohypophy- sis with marked hypervascularity. Case report. Neurol Med Chir (Tokyo) 52:594-598, 2012

12. Fuller GN, Scheithauer BW: The 2007 Revised World Health Organization (WHO) Classification of Tumours of the Central Nervous System: newly codified entities. Brain Pathol 17:304-307, 2007

13. Guadagno E, Cervasio M, Di Somma A, Califano M, Solari D, Del Basso De Caro M: Essential role of ultrastructural examination for spindle cell oncocytoma: case report of a rare neoplasm and review of the literature. Ultrastruct Pathol 40:121-124, 2016

14. Hasiloglu ZI, Ure E, Comunoglu N, Tanriover N, Oz B, Gazioglu N, et al: New radiological clues in the diagnosis of spindle cell oncocytoma of the adenohypophysis. Clin Radiol 71:937.e5-937.e11, 2016

15. Kloub O, Perry A, Tu PH, Lipper M, Lopes MB: Spindle cell oncocytoma of the adenohypophysis: report of two recurrent cases. Am J Surg Pathol 29:247-253, 2005

16. Lee EB, Tihan T, Scheithauer BW, Zhang PJ, Gonatas NK: Thyroid transcription factor 1 expression in sellar tumors: a histogenetic marker? J Neuropathol Exp Neurol 68:482488, 2009

17. Lopes MBS: The 2017 World Health Organization classification of tumors of the pituitary gland: a summary. Acta Neuropathol 134:521-535, 2017

18. Louis DN, Ohgaki H, Wiestler OD, Cavenee WK, Burger PC, Jouvet A, et al: The 2007 WHO classification of tumours of the central nervous system. Acta Neuropathol 114:97-109, 2007

19. Manoranjan B, Koziarz A, Kameda-Smith MM, Provias JP: Multiple recurrences require long-term follow-up in patients diagnosed with spindle cell oncocytoma of the sella turcica. J Clin Neurosci 43:134-146, 2017

20. Matyja E, Maksymowicz M, Grajkowska W, Olszewski W, Zieliński G, Bonicki W: Spindle cell oncocytoma of the adenohypophysis - a clinicopathological and ultrastructural study of two cases. Folia Neuropathol 48:175-184, 2010

21. Mete O, Lopes MB: Overview of the 2017 WHO Classification of Pituitary Tumors. Endocr Pathol 28:228-243, 2017

22. Mete O, Lopes MB, Asa SL: Spindle cell oncocytomas and granular cell tumors of the pituitary are variants of pituicytoma. Am J Surg Pathol 37:1694-1699, 2013

23. Miller MB, Bi WL, Ramkissoon LA, Kang YJ, Abedalthagafi M, Knoff DS, et al: MAPK activation and HRAS mutation identified in pituitary spindle cell oncocytoma. Oncotarget 7:37054-37063, 2016

24. Mlika M, Azouz H, Chelly I, Saïd IB, Jemel H, Haouet S, et al: Spindle cell oncocytoma of the adenohypophysis in a woman: a case report and review of the literature. J Med Case Reports 5:64, 2011

25. Mu Q, Yu J, Qu L, Hu X, Gao H, Liu P, et al: Spindle cell oncocytoma of the adenohypophysis: two case reports and a review of the literature. Mol Med Rep 12:871-876, 2015

26. Ogiwara H, Dubner S, Shafizadeh S, Raizer J, Chandler JP: Spindle cell oncocytoma of the pituitary and pituicytoma: two tumors mimicking pituitary adenoma. Surg Neurol Int 2:116, 2011

27. Osman M, Wild A: Spindle cell oncocytoma of the anterior pituitary presenting with an acute clinical course due to intraventricular hemorrhage. A case report and review of literature. Am J Case Rep 18:894-901, 2017

28. Romero-Rojas AE, Melo-Uribe MA, Barajas-Solano PA, Chinchilla-Olaya SI, Escobar LI, Hernandez-Walteros DM: Spindle cell oncocytoma of the adenohypophysis. Brain Tumor Pathol 28:359-364, 2011

29. Roncaroli F, Scheithauer BW, Cenacchi G, Horvath E, Kovacs K, Lloyd RV, et al: 'Spindle cell oncocytoma' of the adenohypophysis: a tumor of folliculostellate cells? Am J Surg Pathol 26:1048-1055, 2002 
30. Rotman JA, Kucharczyk W, Zadeh G, Kiehl TR, Al-Ahmadi $\mathrm{H}$ : Spindle cell oncocytoma of the adenohypophysis: a case report illustrating its natural history with 8 -year observation and a review of the literature. Clin Imaging 38:499-504, 2014

31. Sali A, Epari S, Tampi C, Goel A: Spindle cell oncocytoma of adenohypophysis: review of literature and report of another recurrent case. Neuropathology 37:535-543, 2017

32. Singh G, Agarwal S, Sharma MC, Suri V, Sarkar C, Garg A, et al: Spindle cell oncocytoma of the adenohypophysis: report of a rare case and review of literature. Clin Neurol Neurosurg 114:267-271, 2012

33. Vajtai I, Beck J, Kappeler A, Hewer E: Spindle cell oncocytoma of the pituitary gland with follicle-like component: organotypic differentiation to support its origin from folliculostellate cells. Acta Neuropathol 122:253-258, 2011

34. Vajtai I, Sahli R, Kappeler A: Spindle cell oncocytoma of the adenohypophysis: report of a case with a 16-year follow-up. Pathol Res Pract 202:745-750, 2006

35. Vuong HG, Kondo T, Tran TM, Oishi N, Nakazawa T, Mochizuki K, et al: Spindle cell oncocytoma of adenohypophysis: Report of a case and immunohistochemical review of literature. Pathol Res Pract 212:222-225, 2016

36. Zygourakis CC, Rolston JD, Lee HS, Partow C, Kunwar S, Aghi MK: Pituicytomas and spindle cell oncocytomas: modern case series from the University of California, San Francisco. Pituitary 18:150-158, 2015

\section{Disclosures}

The authors report no conflict of interest concerning the materials or methods used in this study or the findings specified in this paper.

\section{Author Contributions}

Conception and design: Laws, Giantini Larsen, Cote, Zaidi, Smith, Jane. Acquisition of data: Giantini Larsen, Cote, Zaidi, Bi, Schmitt, Iorgulescu, Miller, Lopes, Jane. Analysis and interpretation of data: Giantini Larsen, Cote, Schmitt, Miller, Lopes. Drafting the article: Giantini Larsen, Cote, Schmitt. Critically revising the article: Laws, Giantini Larsen, Cote, Zaidi, Bi, Schmitt, Iorgulescu, Miller, Smith, Lopes. Reviewed submitted version of manuscript: all authors. Approved the final version of the manuscript on behalf of all authors: Laws. Administrative/technical/ material support: Laws. Study supervision: Laws, Smith, Jane.

\section{Supplemental Information}

\section{Previous Presentations}

Portions of this work were presented in electronic poster form at the American Association of Neurological Surgeons (AANS) meeting, Chicago, Illinois, April 30, 2016.

\section{Correspondence}

Edward R. Laws Jr.: Brigham and Women's Hospital, Harvard Medical School, Boston, MA. elaws@partners.org. 